\title{
Iconografia e política na África do Sul: a representação de Nelson Mandela, Thabo Mbeki e Jacob Zuma nas charges de Zapiro
}

\author{
Autor: Renata de Paula dos Santos \\ Orientador: Rozinaldo Antonio Miani
}

Resumo: A vitória de Mandela nas eleições de 1994 na África do Sul é um marco referencial para a história sul-africana e representou a transição do apartheid para a democracia multirracial. Desde então Nelson Mandela (1994-1999), Thabo Mbeki (1999-2008) e Jacob Zuma (2009-atual), ocuparam o cargo de presidente do país e conduziram, cada um a seu modo, os novos rumos do país. Durante os quase vinte anos de democracia multirracial, um chargista em especial, Jonathan Shapiro, popularmente conhecido pelo pseudônimo de Zapiro, retratou o cotidiano dessa história. Nesse sentido, o objetivo desta pesquisa é analisar como Zapiro retratou os aspectos políticos e sociais, bem como as características psicológicas de cada um dos três presidentes pós-apartheid e quais representações sociais se constituíram a partir de sua produção chárgica. A opção por Zapiro se explica por sua oposição abertamente declarada ao apartheid e também por ser o chargista sul-africano mais conhecido no exterior. Elegemos a charge como objeto de estudo por se tratar de um objeto comunicativo iconográfico constituído pelo humor, que agrega à sua constituição argumentos de transgressão à ordem vigente, possibilitando uma análise da história sulafricana por um viés crítico. Como métodos para o desenvolvimento do trabalho, optamos por reunir a pesquisa histórica, a pesquisa bibliográfica e a análise do discurso chárgico. Entre os referenciais teóricos destacam-se Magnoli (1998; 2009), Jonge (1991) e Carlin (2009) na questão sul-africana; nas reflexões acerca das representações sociais, recorremos a Moscovici (2011) e Jodelet (1993); no campo da charge e do humor, as referências são Miani (2005; 2012), Romualdo (2000) e Eco (1989). Com a realização das análises, pudemos verificar que Zapiro atua de maneiras distintas na construção da representação de cada um dos presidentes em questão e que o chargista apresenta Mandela como um líder competente marcado pelo heroísmo e a referência a ser seguida pelos demais políticos.

Palavras-chave: Charge política. África do Sul. Arte e comunicação. 


\title{
Iconography and Politics in South Africa: the representation of Nelson Mandela, Thabo Mbeki and Jacob Zuma in cartoons of Zapiro
}

\begin{abstract}
Mandela's victory in the 1994 elections in South Africa is a reference point for South African history and represented the transition from apartheid to multiracial democracy. Since then Nelson Mandela (1994-1999), Thabo Mbeki (1999-2008) and Jacob Zuma (2009 - current), occupied the post of president of the country and led, each in its own way, the new direction of the country. During the nearly twenty years of multiracial democracy, one in particular cartoonist, Jonathan Shapiro, popularly known by the pseudonym Zapiro, portrayed the everyday life of this story. In this sense, the objective of this research is to analyze how Zapiro portrayed the political and social aspects, as well as the psychological characteristics of each of the three postapartheid presidents and which social representations are formed from their cartoon production. The choice of Zapiro explained by openly declared his opposition to apartheid and also for being the best known outside South African cartoonist. We elected to cartoon as an object of study because it is an iconographic object constituted by communicative humor, which adds to its constitution arguments transgression of the established order, enabling an analysis of South African history through a critical bias. As methods for the development of the work, we decided to gather historical research, the literature search and analysis of cartooon speech. Among the theoretical frameworks stand out Magnoli (1998, 2009), Jonge (1991) and Carlin (2009) in the South African question; reflections about social representations, we resort to Moscovici (2011) and Jodelet (1993), in the field the cartoon and humor, the references are Miani (2005; 2012), Romualdo (2000) and Eco (1989). With the completion of the analysis, we observed that Zapiro acts in different ways in the construction of the representation of each of the presidents in question and that the cartoonist presents Mandela as a competent leader marked by heroism and reference to be followed by other politicians.
\end{abstract}

Keywords: Art and communication. Charge policy.

Dissertação completa disponível em: http://www.bibliotecadigital.uel.br/ document/?view $=$ vtls000190570 